\title{
THE STUDY OF LAW ON INVESTMENT LIBERALISATION POLICIES IN THE REGION OF ASEAN AND THE EFFECTS ON INDONESIA
}

\author{
Delfiyanti \\ Faculty of Law, Andalas University, Padang \\ Email : defi_anti@yahoo.com
}

\begin{abstract}
In order to realize a single ASEAN market through the free flow of investment in ASEAN, the ASEAN member states have agreed on the ASEAN Comprehensive Investment Agreement or known by the term ACIA signed in Cha-Am (Thailand) on February 26, 2009. The issue is how the rule of law against the liberalization of foreign investment in the ACIA Agreement and how its influence on Indonesia. This research method is a normative juridical research by using a qualitative data analysis technique. Based on the Article 1 (a) of ACIA related to the purpose of the establishment of ACIA the ACIA Agreement contains the legal concept of foreign investment: an investment regime that is "free and open" in ASEAN in order to achieve the ultimate goal of economic integration within the ASEAN Economic Community. This is done through progressive liberalization measures on investment regimes in the Member States of ASEAN. The concept of investment liberalization in the ASEAN region is also well supported by the principles of National Treatment (Article 5 of ACIA) and the principles of Most Favored Nation Treatment/MFN Treatment (Article 6, paragraph 1 of ACIA) in which these two principles are widely known as the principles of law in international economic law. While Indonesia itself has been also engaged in signing and ratifying the ACIA Agreement through Presidential Regulations Number 49 of 2011. This certainly provides a challenge and an opportunity to take advantage of this Agreement, as well as adjust the settings of Indonesian foreign investment (Law Number 25 of 2007) with the consent of the ACIA.
\end{abstract}

Keywords: Implementation; Liberalization of Investment; ASEAN Region; Influence and Indonesia.

\section{A. INTRODUCTION}

ASEAN Economic Community (AEC) is the ultimate goal of economic integration that is contained in the ASEAN Vision 2020 that is moved forward into 2015. The initial phase is characterized by the existence of a "common market" and a single production base through the movement of goods, services and investment, labor as well as freer capital. The formation of the ASEAN Economic Community will provide opportunities for ASEAN

483 Yustisia Vol. 6 Number 3 (September - December 2017) The Study Of Law On Investment....

(C) 2017; This is an Open Access Research distributed under the terms of the Creative Commons Attribution Licensee (https://creativecommons.org/licenses/by/4.0), which permits unrestricted use, distribution, and reproduction in any medium, provided the original work is properly cited. 
member states to expand the scope of economies of scale, improving the goal attraction for investors and tourists, reducing the transaction costs of trade and improving trade and business facilities. In addition, the establishment of the ASEAN Economic Community will also provide the convenience and increase of intra-ASEAN market access and increasing transparency and accelerating the adjustment of domestic regulations and standardization.

The establishment of the ASEAN Economic Community is also a thing that must be done by the ASEAN member states in order to face the global economy and liberalization of international trade. In addition, it is also driven by the growing number of organizations or regional economic blocs that continue to be in line with changes towards a free market economy in the form of trade liberalization. In this case, the economic regionalization has become a way to improve the international competitiveness of enterprises in the region. Various forms of trade agreements (customs union, free trade area and single market) within certain limits provide free-market benefits such as economies of scale in production, while at the same time blocking the benefits for outsiders, unless they invest into internal market and meet the demands of member states for technology transfer and job creation. According to Robert Gilpin and Jean Milis that regionalization is also a facility of collecting the resources and the establishment of regional corporations, such that it has become an important strategy used by the groups of countries to improve their economic and political power (Robert Gilpin and Jean Milis Gilpin, 2002: 379). Thus, the establishment of the ASEAN Economic Community as one of the regional organizations in the economic field needs to be done in order to strengthen regional economic cooperation in the ASEAN region.

Some time ago the ASEAN have agreed to create a new legal instrument replacing the Bangkok Declaration, namely the ASEAN Charter. Establishment of the ASEAN Charter as a new legal instrument for ASEAN significant since ASEAN countries have mutually large interests and through their cooperation mechanism will get a lot of comparative advantages 
(Jagdish Sachdev, 1978: 33). The desire to integrate ASEAN economies through the agreement to establish the ASEAN Economic Community is an effort to improve the economy of the countries in the region. As Cunan's view which finds that the economic cooperation in a region needs to be improved in order to improve the welfare of the people who were in that area and is done through a treaty or agreement as in the ASEAN Economic Community (AEC) (Cunan, 1999: 21).

Furthermore, in the framework of the ASEAN Economic Community also created the ASEAN Economic Community Blueprint which includes the stages of economic integration to be achieved by the ASEAN ahead through 4 (four) frameworks or pillars which include (Rizal A. Djaafara dan Aida S Budiman, 2008: 15-16):

1. ASEAN as a single market and production base with an element of international free flow of goods, services, investment, skilled labor, and freer flow of capital.

2. ASEAN as a region with high economic competitiveness, with elements of competition rules, consumer protection, intellectual property rights, infrastructure development, taxation and e-commerce.

3. ASEAN as a region with equitable economic development with elements of the small and medium enterprise development and the ASEAN integration initiatives for CLMV countries contained in the Initiative for ASEAN Integration.

4. ASEAN as a region fully integrated into the global economy with elements of a coherent approach to the economy outside of the region and increase participation in global production networks.

ASEAN wishes to increase economic cooperation and regional integration through the establishment of the ASEAN Charter and the ASEAN Economic Community Blueprint above is an attempt to bind the member states of ASEAN to be more committed to the existing agreement. This is due during treaties existing implementations lack running optimally due to lack of enforcement and the many social factors that influence in the region (Eric 
Stein, 2001: 489). "In fact, the member states of ASEAN mutual interests are large and through the mechanism of cooperation they will acquire many comparative advantages (Jagdish Sachdev, 1978: 33). This will is one of the challenges in the implementation of the ASEAN Economic Community in the future.

In the blueprint of the ASEAN Economic Community in 2015 mentioned, ASEAN wants to realize the single market with the free flow of traffic among the field of "investment" as contained in Article 5, paragraph 1 of the ASEAN Charter, namely:

"To create a single market and procution base which is stable, prosperous, highly competitive and economically integrated with effective facilitation for trade and investment; facilitated movement of business persons, professionals, talents and labor; and freer low of capital."

Then the member states of ASEAN agreed on the ASEAN Comprehensive Investment Agreement (ASEAN Comprehensive Investment Agreement or ACIA) signed in Cha-Am (Thailand) on 26 February 2009. The ACIA Agreement itself is a revision and combination of two (2) pieces agreements investments that have been agreed ASEAN previous Framework Agreement on Region Investment ASEAN \{Framework Agreement on the ASEAN Investment Area, or AIA Agreement) of 1998 and the ASEAN Agreement for the Promotion and Protection of Investments (ASEAN Agreement for the Promotion and Protection of Investment) of 1987, known as the ASEAN Investment Guarantee Agreements (ASEAN IGA) (Thailand Board of Investment, 2016).

ACIA Agreement is an investment approval or the overall investment in ASEAN which aims to create a regime of investment that is free and open in ASEAN in order to achieve the ultimate goal of economic integration within the ASEAN Economic Community (AEC) in accordance with the Blueprint of the ASEAN Economic Community by doing measures which are "progressive liberalization 'of investment regimes in the Member States of ASEAN (progressive liberalization of the investment regimes of Member States) (ASEAN Comprehensive Investment Agreement, 2009). Therefore, 
all the member states of ASEAN will implement liberalization in investment extensively with based on the concept contained in the ASEAN Comprehensive Investment Agreement (ACIA).

Investment is one area participating the ASEAN Economic Community that aims to integrate the flow of investment among ASEAN member states, as there is a positive relationship and synergy between regional integration and FDI which can increase investment (Te Velde, Dirk Willem and Bezemer, 2006: 41). In the view of M. Somarajah the ASEAN Comprehensive Investment Agreement (2009) is also a combination of movements in the ASEAN investment liberalization and protection of investments in the region. Therefore, the main purpose of this agreement is to provide a balance between the protection of investments and maintenance of investment rules that are under the control of national importance (M. Somarajah, 2010: 225).

This ACIA agreement has been signed and ratified by all member states of ASEAN. Indonesia itself has also signed and ratified the ACIA Agreement through Presidential Regulations Number 49 of 2011 on the Ratification of the ASEAN Comprehensive Investment Agreement on August 8, 2011 such that Indonesia has been bound to run the contents of the agreement and involved in comprehensive investment liberalization in ASEAN.

\section{B. PROBLEM STATEMENT}

Based on the introduction, for Indonesia, this is a challenge and an opportunity to increase investment or foreign investment into Indonesia. Another thing that is equally important how the alignment of the provisions of the ACIA Agreement which aims to liberalize investment in the ASEAN region with the provisions of the applicable investment in Indonesia, especially with Law Number 25 of 2007 on Investment. 


\section{RESEARCH METHODS}

This study uses a "normative juridical research 'conducted by examining the library materials or secondary data (Soerjono Soekanto dan Sri Mamudji, 2010: 13). Furthermore, secondary data supported by primary data through field research by interviewing relevant resource persons and experts on this issue. The research was supported by the law also by the legal historical method, comparative law and the law that will come (CFG Soenaryati Hartono, 2006: 144-146). This normative juridical research using primary, secondary and tertiary legal materials.

In addition, this study is explorative in order to see the picture of the general shape of this Agreement in the review of the legal aspects and legal principles in the ACIA which at later will be effective in all member states of ASEAN in the field of investment. In addition, this study uses the "qualitative data analysis" technique.

\section{RESEARCH RESULT AND DISCUSSION}

\section{D.1. Implementation of Investment in ASEAN Region}

ACIA Agreement consists of 49 articles in which the consent of the ACIA is a part of the implementation of the blueprint of the ASEAN Economic Community in order to realize the ASEAN as a single market and production base with one of the main elements of the free flow of investments or investments (free flow of investment). In general, the ACIA Agreement aims to increase the activity of investment among ASEAN member states and make the region competitive ASEAN to become one of the points of interest of investors in the world (Priskila Pratita Penasthika, 2013: 67). ACIA Agreement shall apply to investments existing at the date of entry into force of this Agreement as well as for investments made after the entry into force of this Agreement (ASEAN Comprehensive Investment Agreement, 2009: Article 3). More details in this it has been seen in the goal of establishment of ACIA Agreement stated in Article 1 of ACIA that is: 
"The objective of this Agreement is to create a free and open investment regime in ASEAN in order to achieve the end goal of economic integration under the AEC in accordance with the AEC Blueprint, through the following:

(a) progressive liberalization of the investment regimes of Member States;

(b) provision of enhanced protection to investors of all Member States and their investments;

(c) improvement of transparency and predictability of investment rules, regulations and procedures conducive to increased investment among Member States;

(d) joint promotion of the region as an integrated investment area; and

(e) cooperation to create favorable conditions for investment by investors of a Member State in the territory of the other Member State.

Based on The Article 1 of the above objectives of the ACIA Agreement is to create an investment regime that is free and open (A Free and Open Investment Regime) in ASEAN in order to achieve the ultimate goal of economic integration within the ASEAN Economic Community in accordance with the ASEAN Economic Community Blueprint. Under these conditions, the legal regulation of foreign investment in the ACIA embrace an investment regime that is "free and open" open (A Free and Open Investment Regime) in ASEAN.

Investment regime that is "free and open" open (A Free and Open Investment Regime) in ASEAN realized through the actions of "progressive liberalization on investment regimes in the Member States"; provision increase better protection to investors from all Member States and investments; increased transparency and predictability of rules, regulations and procedures conducive investment to increase investment in the Member States; joint promotion of the region as an area of integrated investment and cooperation to create favorable condition for investments made by investors of a Member State in the territory of the other Member States.

In the framework of the liberalization of the foreign investment that 
is free and open in the ASEAN ACIA Agreement is also supported by some of the principles that are widely used and recognized in international agreements as contained in Article 2 that is:

"This Agreement shall create a liberal, facilitative, transparent and competitive investment environment in ASEAN by adhering to the following principles:

(a) provide for investment liberalization, protection, investment promotion and facilitation;

(b) progressive liberalization of investment with a view towards achieving a free and open investment environment in the region;

(c) benefit investors and their investments based in ASEAN;

(d) maintain and accord preferential treatment among Member States;

(e) no back-tracking of commitments made under the ACA Agreement and the ASEAN IGA;

(f) grant special and differential treatment and other flexibilities to Member States depending on their level of development and sectoral sensitivities;

(g) reciprocal treatment in the enjoyment of concessions among Member States, where appropriate; and

(h) accommodate expansion of scope of this Agreement to cover other sectors in the future

This ACIA Agreement also contains a variety of settings foreign investment law which serve as guidelines for all member states of ASEAN in cooperation and investments in the framework of the liberalization of investment ASEAN region. Some arrangements concerning the provision of investment liberalization among others are related to the scope of the entry into force of the ACIA under Article 3 paragraph (1) and (2) shall apply to that ACIA. In further, based on Article 3 paragraph (3) ACIA Agreement the scope of the liberalization of investment covers sectors:

"For the purpose of liberalization and subject to Article 9 (Reservations), this Agreement shall apply to the following sectors: manufacturing; agriculture; fishery; forestry;mining and quarrying;services incidental to manufacturing, agriculture, fishery, forestry, mining and quarrying; and any other sectors, as may be agreed upon by all Member States."

In order to support the liberalization of foreign investment in ASEAN, the regulation foreign investment law in the ACIA Agreement is also supported by other principles that are recognized and many used by 
the community internationally as the principles of National Treatment and The Same Treatment (Most Favored Nation Treatment/MFN Treatment). In the principles of National Treatment this contains the following provisions (ASEAN Comprehensive Investment Agreement, 2009: Article $5)$ :

1. Each Member State shall accord to investors of any other Member State treatment no less favorable than that it accords, in like circumstances, to its own investors with respect to the admission, establishment, acquisition, expansion, management, conduct, operation and sale or other disposition of investments in its territory.

2. Each Member State shall accord to investments of investors of any other Member State treatment no less favorable than that it accords, in like circumstances, to investments in its territory of its own investors with respect to the admission, establishment, acquisition, expansion, management, conduct, operation and sale or other disposition of investments.

While in principles the same Treat (Most Favored Nation Treatment/MFN Treatment) contains a provision that (ASEAN Comprehensive Investment Agreement, 2009: Article 6):

"Each Member State shall accord to investors of another Member State treatment no less favorable than that it accords, in like circumstances, to investors of any other Member State or a non-Member State with respect to the admission, establishment, acquisition, expansion, management, conduct, operation and sale or other disposition of investments."

In the principles of MFN Treatment then each Member State shall accord to investors of any other Member State treatment not less favorable than that accorded, in similar circumstances, to investors of any other Member State or of a State not a Member with regard to licensing, establishment, acquisition, expansion, management, implementation, operation and sale or disposal of other investments.

The principles of Most Favored Nation (MFN) is also a fundamental principles in International Economic Law Treaty. According to Schwarzenberger principally MFN clause is the principles of nondiscrimination between the countries. This principles requires, a country 
must give rights to other countries as well as he gives similar rights to a third country (Schwarzenberger, 1962: 230). But the MFN principles it contains numerous exceptions as shown in the covenants of international economic law. For example, there is an exception in the GATT MFN obligation is for regional organizations or area or free trade area. Another exception is allowable for application or granting GSP (Generalized System of Preferences). GSP is giving treatment more competitive tariff level (low) to trade products from developing countries (Huala Adolf, 2010: 26). The same thing also expressed by Debra P. Steger that the WTO Agreement pursuant to Article XXIV provides exceptions related to the implementation of the principles of MFN trade agreements in a region (William J. Davey and John Jacson (Ed), 2008).

Thus, the principles of National Treatment (National Treatment) and Treat Same (Most Favored Nation Treatment) contained in the ACIA in essence prohibits discrimination (non-discrimination) committed against foreign investors (foreign investors) as well as investments made amongst ASEAN member states. Therefore, each Member State shall provide fair and equitable treatment and protection and security for investments are fully protected from investors of any other Member State investments are protected (Article 11 paragraph 1 of ACIA). In addition, the act of discrimination is contrary to the liberalization of investment regimes that are set in the ACIA where their freedom in the traffic flow of investment or investment in the ASEAN region.

In the end, the goal of investment liberalization policy through inflows of new investment and investment return that will enhance and ensure a dynamic economy in the member states of ASEAN and ultimately improve the economic and social development as a whole in the ASEAN as enshrined in the Preamble ACIA Agreement namely: "... conducive investment environment will Enhance freer flow of capital, goods and services, technology and human resource and overall economic and social development in ASEAN. " 
Based on the aforementioned opening in the ASEAN agreed to ensure sustainable development that will benefit generations present and future and put the well-being and the livelihood and welfare of the people as the center of the ASEAN community building process. In the end, as stated in Article 1 of the Charter confirmed the establishment of a single market one of which aims to improve the welfare and decent livelihood for the people of ASEAN through the provision of equal access to the opportunities of human resource development, social welfare and justice.

\section{D.2. The Effects On Indonesia}

Indonesia's participation in international treaty is already a thing no more inevitable in the global economy as it is now. Along with the increasing cooperation between countries is also increasingly increasing interdependence among countries. One of them, Indonesia has joined as participants in regional international arrangements is to participate in signing the ASEAN Comprehensive Investment Agreement (ASEAN Comprehensive Investment Agreement) dated February 26, 2009 in Chaam (Thailand). ACIA Agreement itself aims to create a regime of investment that is "free and open" (a free and open Investments regime) in ASEAN in order to achieve the ultimate goal of economic integration within the ASEAN Economic Community through measures that progressive liberalization on regimes planting capital in the ASEAN Member states (Article 1 and 2 of ACIA).

Furthermore, Indonesia has ratified the ACIA Agreement through Presidential Regulations Number 49 of 2011 on the Ratification of the ASEAN Comprehensive Investment Agreement on 08 August 2011. The ratification required in ACIA Agreement as stated in the Article 48 paragraph (1) of ACIA which requires ratification by all ASEAN Member states including Indonesia. ACIA Agreement ratification by Indonesia then give the effect that under Article 3 of Presidential Regulations Number 49 In 2011, the number of provisions revoked and declared no longer valid, 
namely Presidential Regulations Number 22 of 1988 on Ratification of an Agreement Among the Governments of Brunei Darussalam, the Republic of Indonesia, Malaysia, the Republic of the Philippines, the Republic of Singapore, and the Kingdom of Thailand for the Promotion and Protection of Investments (State Gazette Republic of Indonesia of 1988 Number 15) and Presidential Regulations Number 28 of 1999 on Ratification of the Framework Agreement on the ASEAN Investment Area (the Framework Agreement on the ASEAN Investment Area) (State Gazette of the Republic of Indonesia of 1999 Number 40).

In addition, another effect of the Agreement has been ratified by Indonesian ACIA is their attachment to Indonesia to follow the provisions contained in the ACIA Agreement. One of them is necessary to adjust the provision of investment set out in the ACIA Agreement towards investment law Indonesia as stated in Article 26 of the ACIA (Member States recognize the importance of fostering ASEAN economic integration).

For Indonesia, the adjustment in question is by Law Number 25 of 2007 on Investment Law (hereinafter referred to as Investment Law) that apply now in Indonesia (Law Number 25 of 2007 on Investment Law). This Law established replaces legislation investment foregone namely Law Number 1 of 1967 on Foreign Investment, as amended by Law Number 11 of 1970 on the Amendment and Supplement Law Number 1 of 1967 on Foreign Investment and Law Number 6 of 2968 concerning Domestic Investment, as amended by Law Number 12 of 1970 on the Amendment and Supplement Law Number 6 of 1968 on Domestic Investment. As stated in Article 38 of the Investment Law stated that with the Law Number 25 of 2007, the old law has been declared null and void.

The difference with the old legislation, namely the difference between the regulation of foreign investment (FDI) and Domestic Investment (DCI), then in the Investment Law which applies now, the issue of foreign investment and domestic regulated in one unit. 
Differentiation foreign investments and domestic investments have been made in the context of identifying the origin of the capital, whether it comes from domestic sources or from foreign sources, or by those who conduct such investment, whether local investors/domestic or foreign investors (David Kairupan, 2013: 11). Thus, the legal regulation in the Indonesian investment not done anymore distinction between foreign direct investment (FDI) and domestic investment (DCI), but it is set in the statute is Law Number 25, 2007 (Capital Market Law).

Currently, the Investment Law that gives the regulatory framework of foreign investment or foreign investment in Indonesia, which serve as guidelines for foreign investors or foreign investors to invest in Indonesia as stated in Article 2 that the provisions of this Act shall apply to investment capital in all sectors in the territory of the Republic of Indonesia. Based on the Investment Law, the Government has an obligation to establish a policy for investment in Indonesia, which serve as guidelines for investors or investors to invest in Indonesia. Determination of basic policy of investment by the government in order to encourage the creation of national business climate conducive to investment in order to strengthen the competitiveness of the national economy and accelerate an increase in investment in Indonesia (Article 4 paragraph (1) Investment Law).

In connection with the Agreement has been ratified by Indonesia, the ACIA necessary adjustments where possible by Law Number 27, 2007 (Indonesian Investment Law) in the framework of the ASEAN Economic Community as stated in Article 26 (a) of ACIA. In this case, need to see some provisions in the Indonesian Investment Law regarding foreign investments have compatibility with the contents of the charge in the ACIA Agreement.

Some of the provisions of which, in Article 4 (2a) of the Indonesian Investment Law provides for the granting of equal treatment for domestic investors and foreign investors with regard to national interests. Based on the article, foreign investors making investment in Indonesia should be given the same treatment as domestic investors without discrimination. It further relates to Article 6 paragraph (1) Investment Law reads:

" The government gives equal treatment to all investors originating from any country that conduct investment activities in Indonesia in 
accordance with the provisions of the legislation. "

According to Article 3 (d) Investment Law clearly states that this legislation contains the principles of equal treatment and did not distinguish the country of origin. The imposition of foreign investment as stipulated in Article 3 (d), Article 4 (2a) and Article 6 paragraph (1) of the Investment Indonesia in line with Article 5 and Article 6 paragraph (1) of the ACIA Agreement governing similar things related to the principles of National Treatment (National Treatment) and Treat Same (Most Favored Nation Treatment/MFN Treatment) in the ASEAN Region. Based on the principles of national treatment are then each Member State shall provide to investors and investments of investors of any other Member State treatment not less favorable than that accorded, in similar circumstances, as given to growers own capital with regard to licensing, establishment, acquisition, expansion, management, implementation, operation and sale or disposal of other investments in its territory.

In the principles of MFN Treatment then each Member State shall accord to investors of any other Member State treatment not less favorable than that accorded, in similar circumstances, to investors of any other Member State or of a State not a Member with regard to licensing, establishment, acquisition, expansion, management, implementation, operation and sale or disposal of other investments.

Thus, the Indonesian Investment Law also embraces the principles of National Treatment (National Treatment) and Treat Same (Most Favored Nation Treatment/MFN Treatment) as well as contained in the ACIA Agreement so that the Investment Law have joined in support of their foreign investment liberalization. The second principles is a recognized principles in international arrangements and used by the international community. Adjustments to the provisions in force in the international community (especially ACIA Agreement) needs to be done by Indonesia in the Investment Law as stated in the Preamble to the Investment Law in order to face global economic changes and Indonesia's 
participation in various cooperative international need to create investment climate conducive, promotive, provide legal certainty, fairness, and efficient by taking into account the interests of the national economy. It aims among other things to boost national economic growth, create jobs and promote sustainable economic development and to encourage national business climate conducive to investment (Article 3 paragraph (2) point (a), (b), and (c) of Investment Law ) in order to strengthen the competitiveness of the national economy and accelerate an increase in investment (Article 4 paragraph (1) point (a) of Investment Law).

One indicator to increase inflow of foreign investments into the territory of a country is the lack of legal certainty and tried in the country. Related to Article 14 (a) of the Investment Law Indonesia above that the investor is entitled to get legal certainty. In Article 4 paragraph (2b) Investment Indonesia emphasize again that the government should ensure legal certainty, certainty and security attempted to investors since the licensing process until the end of investment activities in accordance with the provisions of the legislation. Furthermore, in Article 30 paragraph (1) states that the Government and/or regional government to ensure certainty and security sought for the implementation of investment.

Thus, the regulation of foreign investment in the Investment Law in Indonesia related to legal certainty and security to invest in global through Article 4 (2b), Article 14 (a) and Article 30 paragraph (1) of the Indonesian Capital Law of the in harmony with the above provisions are also contained in Article 11 of the ACIA Agreement. In the ACIA Agreement stated that each member state is obliged to provide fair and equitable treatment and protection and security for investments are fully protected from the investors of each member state (Article 11 of ASEAN Comprehensive Investment Agreement, 2009).

Therefore, based on the results of the analysis has been done on some of the provisions contained in Law Number 25 of 2007 on The Indonesian Investment Law, the regulation of foreign direct investment 
(FDI) in Indonesian Investment Law in general are in accordance with the ACIA Agreement. Thus, the provision contained in the ACIA are also found in the Investment Law in Indonesia although certain parts are still differences and the need for completing. As in the ACIA Agreement where in Article 12 of ACIA regulate the issue of compensation in the riots (Compensation in Cases of Strife) which each Member State shall accord to investors of any other Member State, related to investments protected, which suffered losses in its territory because of armed conflict or civil unrest or state of emergency, non-discriminatory treatment related to restitution, compensation or other consideration valued. While in Indonesian Investment Law are not related to compensation arrangements in the event of unrest.

In general, the rules contained Law Number 25, 2007 (Indonesian Investment Law) was appropriate and in sync with the ACIA Agreement so that the rules contained in the ACIA Agreement already accommodated in some of the provisions contained in the Law on Investment Indonesia. Thus, Indonesia also encourage joint investment liberalization in the ASEAN region. Any changes in the rules of foreign investment in Indonesia contained in Law Number 25 in 2007 with the Investment Law that long where Law Number 25 of 2007 has been adjusted and harmonized with international provisions particularly ACIA Agreement is to anticipate changes in the global economy.

In the end, adjustments to some of the provisions in force in the international community (especially ACIA Agreement) conducted by Indonesia in the Investment Law was in order to face global economic changes and Indonesia's participation in various international cooperation necessary to create investment climate that conducive, promotive, provide legal certainty, fairness and efficient manner with due regard to the interests of the national economy, as stated in the Preamble of the Investment law. It aims among other things to boost national economic growth, create jobs and promote sustainable economic development 
(Article 3 (2) point (a), (b), and (c) of Investment Law ) in order to encourage the creation of national business climate conducive to investment in order to strengthen the competitiveness of the national economy and accelerate an increase in investment (Article 4 paragraph (1) point (a) of Investment Law).

\section{E. CLOSSING}

\section{E.1. Conclusion}

The regulation of the foreign investment law in the ACIA Agreement follows a Free and Open Investment Regimen in ASEAN in order to achieve the ultimate goal of economic integration in the Community ASEAN economic. This is done through the actions of "progressive liberalization on investment regimes in the Member States" as contained in Article 1 (a) and Article 2 of the ACIA Agreement. In addition, to support the liberalization of investment, the ACIA Agreement also contains some of the principles in which this principles is recognized and widely used by the international community including the principles of National Treatment (National Treatment) under Article 5 of the ACIA and Principles Treat Same (Most Favored Nation Treatment/MFN treatment) pursuant to Article 6 paragraph (1) of ACIA. The principles are essentially prohibits discrimination (non-discrimination) made to investors (investors) as well as investments made between fellow ASEAN members. Furthermore, in Article 11 (1) of ACIA where each Member State shall provide fair and equitable treatment and protection and security for investments are fully protected from investors of any other Member State investments are protected.

The influence of the ratification of the Agreement through the ACIA through Presidential Regulations Number 49 of 2011, there are several provisions of investment treaties that had been ever taken as together with other ASEAN member states such as the Ratification of the Framework Agreement on the ASEAN Investment Area (Framework 
Agreement on the ASEAN Investment Area) and others then it revoked and no other enforced. The most important of these implications is Indonesia should strive to align, where possible, the policies of investments in accordance with the provisions of the ACIA as stated in Article 26 (a) of ACIA Agreement. Based on the analysis of some of the provisions contained in the Law Number 25 of 2007 on Investment in Indonesia, the provisions of foreign direct investment (FDI) in the Law on Investment in general has been aligned with the provisions contained in ACIA Agreement as concerns the liberalization of investment, the principles of national treatment and treatment the same (Most Favored Nation Treatment/MFN Treatment), nationalize (nationalization), the takeover of (expropriation), providing facilities ease of investing, legal certainty and security. Thus the provisions contained in the ACIA are also found in the Investment Law although in certain parts are still differences and the need for completing.

\section{E.2. Suggestions}

The existence of various provisions in the Law Number 25 of 2007 Investment neighbor that makes it easy for foreign investors or foreign investors to attract investment in Indonesia should also be supported by consistent implementation. In its implementation is still happening to confusion and not in accordance with existing regulations. As with decentralization, each region issued investment policies of their respective regions sometimes through the administrative process lengthy and add charges - other fees charged to foreign investment or foreign investors that this is one reason they are less willing to invest in Indonesia. This of course will affect the investment climate (investments) in Indonesia.

With the liberalization of investment in ASEAN, the government also should also really give special attention to small businesses, micro, medium, SMEs and cooperatives as it has been included in the Investment Law. In Indonesia, SMEs and cooperatives have an important role in 
meeting people's lives, especially the small and medium communities, mostly in Indonesia. They must be protected and given special treatment so it is not dead and displaced by the influx of foreign investments which have huge capital and open a business in Indonesia.

\section{BIBLIOGRAPHY:}

\section{Books:}

Adolf, Huala, 2010, Hukum Ekonomi Internasional, Suatu Pengantar Cetakan ke 5 (International Economic Law, An Introduction, The Fifth Print), Bandung: PT. Keni Media

Cunan, 1999, Economic Development and Prosperity, Boston, Massatchussets, USA : Harvard University

Davey, William J and John Jacson (Ed), 2008, The Future of International Economic Law, New york: Oxford University Press

Djaafara, Rizal A dan Aida S Budiman, Masyarakat Ekonomi ASEAN 2015, 2008, dalam : Sjamsul Arifin (eds.), Masyarakat Ekonomi ASEAN 2015, 2008, Memperkuat Sinergi ASEAN di Tengah Kompetisi Global (Strengthening ASEAN Synergy Amidst Global Competition), Jakarta: PT. Elex Media Komputindo

Gilpin, Robert and Jean Milis Gilpin, 2002, The Challenge of Global Capitalism (Tantangan Kapitalisme Global), terjemahan Haris Munandar dan Dudy Priatna, Jakarta : PT. RajaGarfindo Persada

Hartono, CFG Soenaryati, 2006, Pengantar Hukum di Indonesia Pada Akhir Abad ke-20 (Introduction to Law In Indonesia at The End of The 20th Century), Bandung: PT. Alumni

Kairupan, David, 2013, Aspek Hukum Penanaman Modal Asing di Indonesia (Legal Aspects of Foreign Investment In Indonesia), Jakarta: PT. Kencana

Schwarzenberger, 1962, Frontier of International Law, London : Steven \& Sons Soekanto, Soerjono dan Sri Mamudji, 2010, Penelitian Hukum Normatif Suatu Tinjauan Singkat, Jakarta, Rajawali Pers Raja Grafindo Persada

Sornarajah, M, 2010, The International Law on Foreign Investment, Cambridge University Press, Third Edition, United Kingdom

\section{International Treaties And Regulations:}

ASEAN Comprehensive Investment Agreement (ACIA) of 2009.

Law Number 25 of 2007 on Investment Law, State Gazette of the Republic of Indonesia Number 67 of 2007

Presidential Regulations Numbe Number 49 of 2011 on the Ratification of ASEAN Comprehensive Investment Agreement.

\section{Journals:}

Penasthika, Priskila Pratita, 2013, The Issues on Personal Status of Investor in the ASEAN Comprehensive Investment Agreement from the Perspective of Private International Law, Indonesian Law Journal, Jakarta, Vol. 6 
Sachdev, Jagdish, 1978, Foreign Investment Policies of Devloping Host Nations and Multinationals : Interaction and Accomodation, Management International Review, Vol. 18, Number 2

Stein, Eric, 2001, International Integaration and Democracy : No Love at Fisrt Sight, American Journal of International Law, Vol. 95, Number 3

Velde, dkk, 2006, Regional Integration anf Foreign Direct Investment in Developing Countries, Transnational Corporations, Vol.15

\section{Website:}

Thailand Board of Investment, "Higlights of The ASEAN Comprehensive Investment Agreement", <http://www.boi.go.th> [accessed on 28th February 2016] 